\title{
Official Medical Documents as a Source for Research of the Fate of Warsaw Jews 1939-1941
}

Only fragments of official medical documents that are the record of the fate of Warsaw Jews have survived. In spite of this, these documents offer a unique perspective and reveal many aspects of the life and the death of Warsaw Jews to the contemporary reader. Among the available official medical documents the most valuable are two collections: death certificates ${ }^{1}$ from 1939-1941 and hospital records from 1939-1940. I am interested in both in two aspects: as a type of document and as a text on the human lot.

In the archives of the Jewish Historical Institute, Warsaw, there are around 11,000 death certificates of Warsaw Jews, who died in 1939 and $1941 .^{2}$ A death certificate is a document, a form filled in by a doctor who established that a patient died, and is made for the Statistical Department of the Municipal Board. The collection in question was accidentally found in the 1990s in the basement

${ }^{1}$ The term "death certificate" (karta zgonu) refers to a document issued by a doctor upon a person's death. On the other hand, there is "registration of death" (akt zgonu), an official document based on the former and made by the authorities, usually municipal or self-government, and kept in a public register.

${ }^{2}$ Another collection that also contains names of the deceased is the Kartoteka zmarłych Żydów [Register of Deceased Jews] compiled by the Lublin Municipal Board (Archiwum Żydowskiego Instytutu Historycznego [Archive of the Jewish Historical Institute], later: AŻIH, 253/6). This collection is only fragmentary - only 94 personal cards survived, filled in during November and December 1941. These documents served a completely different purpose they contain no medical annotations, and were compiled in order to take the inventory of the deceased persons' property. Apart from the basic personal information (name, surname, age, occupation, address), the other boxes pertain to the kind and volume of property, names of inheritors, and existence of a last will. Each card is signed by the municipal controller. Most frequently in the box "Property left" the following was written: "the deceased had no property"; sometimes one could find the address of the flat or house the person owned.

One should also mention the holdings of the Central Statistical Office (Główny Urząd Statystyczny, GUS), which keeps 16,500 packets of personal files from the German occupation, including death certificates (cf. Józef Żeglicki, "W sprawie dat [sic] statystycznych z okresu okupacji hitlerowskiej,” Wiadomości Statystyczne [1966]: 12). These materials are not available. I am grateful to Alina Skibińska for the information on GUS archives. 
of the building at 1 Leszno St. in Warsaw ${ }^{3}$ (where the surgical ward of a hospital was located), and it covers only 1939 and 1941; therefore the collection is incomplete, which is further complicated by the fact that many documents are destroyed and it is impossible to read much of the information they contain. ${ }^{4}$ Out of 11,000 cards, about 1,270 are from 1939, which accounts for 12.7 percent of the entire collection, and 9,700 are from 1941. We do not know how many cards were lost or destroyed, which makes it impossible to formulate any comprehensive statistical picture on the basis of the surviving cards. If we consider that by the time the deportations of Warsaw Jews to the death camp at Treblinka began, in July 1942, around 100,000 people died of hunger and diseases, ${ }^{5}$ and the surviving death certificates cover over 10 percent of deaths. Nevertheless, death certificates are an important source of information about the death rate of Warsaw Jews.

The 1941 certificates were filled in by doctors who established a patient's death, and were the first documents that confirmed a person's demise. At the same time they were the prerequisite for ritual and administrative funeral procedures. Therefore, the death certificate served a purpose, it made possible all kinds of administrative procedures, and was issued separately from the registration of death. The death certificate was sent to the Department of Cemeteries of the Judenrat, and forwarded to the Department of Jewish Population Registration. Later it was sent to the Warsaw Municipal Board (in December 1941, a branch office of the Municipal Board was established in the ghetto, so the registrations of death did not leave the ghetto), and subsequently it was returned to the resident's registration office in the ghetto, where the deceased person was struck off the register, and the issuing of their food coupons stopped. After passing through all these offices, with each recording the deceased into their statistics, a death certificate should have been destroyed. ${ }^{6}$ (Therefore, the surviving death certificates demonstrate the inefficiency of the bureaucratic

\footnotetext{
${ }^{3}$ According to correspondence between the State Archive of Warsaw and the Jewish Historical Institute, in 1952 the Institute's archives also held a collection of war-time Jewish death certificates, found by construction workers in Muranów in 1949 (see AŻIH, Korespondencja ŻIH [JHI correspondence], 2965/1952). The fate of this collection remains unknown. Currently, the only death certificates kept at the JHI are those found in the 1990s.

${ }^{4}$ AŻIH, Rada Żydowska w Warszawie 1939-1945 [sic] (The Jewish Council, Warsaw 1939-1945), 221/16, Death certificates of the Jewish population of Warsaw. The collection was compiled by Monika Taras (née Natkowska), whose diligence made it possible to read and preserve many blurred and damaged entries. Currently, the certificates are available to AŻIH readers in the form of a computer database.

${ }^{5}$ According to Israel Gutman's estimation; see idem, The Jews of Warsaw, 1939-1943: Ghetto, Underground, Revolt, trans. Ina Friedman (Bloomington: Indiana University Press, 1987), 110.

${ }^{6}$ The official circulation of the certificates was frequently interrupted, and the dates on the document demonstrate the inefficiency of the bureaucratic machine - the date when the certificate was filled in was often several weeks later than the date of death.
} 
machinery.) ${ }^{7}$ The circulating document, filled in by one clerk after another, as if a snowball, gathered information, turned into a text.

The death certificate contained basic information on the deceased: his or her surname, first names, gender, date of death and its cause (in Polish or Latin). The physician would sign and stamp it. The other part of the certificate was filled in by a family member, relative or the person in charge of funeral preparations (e.g. head of a refugee home), who provided information on the living conditions or the deceased person's family (spouse, number of children). The third to fill it in was the head of the Statistical Office of the Municipal Board, ${ }^{8}$ who filled relevant boxes with names of parents, date of birth, religious confession, address, marital status, and occupation. For children, it was noted whether they had been born in or outside marriage. The deceased was assigned by this clerk to the various categories, which is confirmed by letters stamped on the certificates - capital B, P or D (their meaning cannot be reconstructed today, so some content of the documents is now completely erased). Thus the document was filled in by at least three persons. Different people added biographical "puzzle pieces" at the different stages.

The death certificate had certain practical functions: it confirmed the change of the status of a given person - from alive to deceased - and sanctioned death in administrative and legal terms. As a result, the deceased lost the last attributes of a person: registration, and food coupons. The status and the dignity of a deceased person was achieved officially. Thus the certificate confirmed the end of a persona - the end of legal capacity. A person with one's own biography became a statistical case. The first paradox of the collection in question consists in the fact that the death certificate collected elements of the deceased person's biography so as to make such a person a statistical case. From a researcher's point of view, the result is the opposite: the certificates are not productive statistically, but make it possible to reconstruct the identity of the individual dead. What was to deprive the person of identity does preserve it (which is particularly the case with unknown dead, referred to as "N.N." [John or Jane Doe]); even though we still know nothing of their identity, we are able to learn many details of ghetto dwellers' biographies).

Another paradox is that such documents are typically the sources of other discourses: obituaries, eulogies or letters of condolences. In 1941, the ghetto death certificates were not a pretext for such discourses [...] Today it is different. A bare document begins to speak, and turns into a narration about an individual and a community. The resultant narration is a kind of collage. The certificates become pieces in a kaleidoscope; depending on how we shake them up, and what pattern they form, a different story ensues.

${ }^{7}$ The official circulation of death certificates was discussed by Gazeta Żydowska, cf. Gazeta Żydowska (87), 19 November, and (122), 10 December 1941.

${ }^{8}$ Most frequently there appear the names of the following municipal officials: Józef Pluskowski, Zdzisław Ostrowski, and Wiktor Sejdak. 


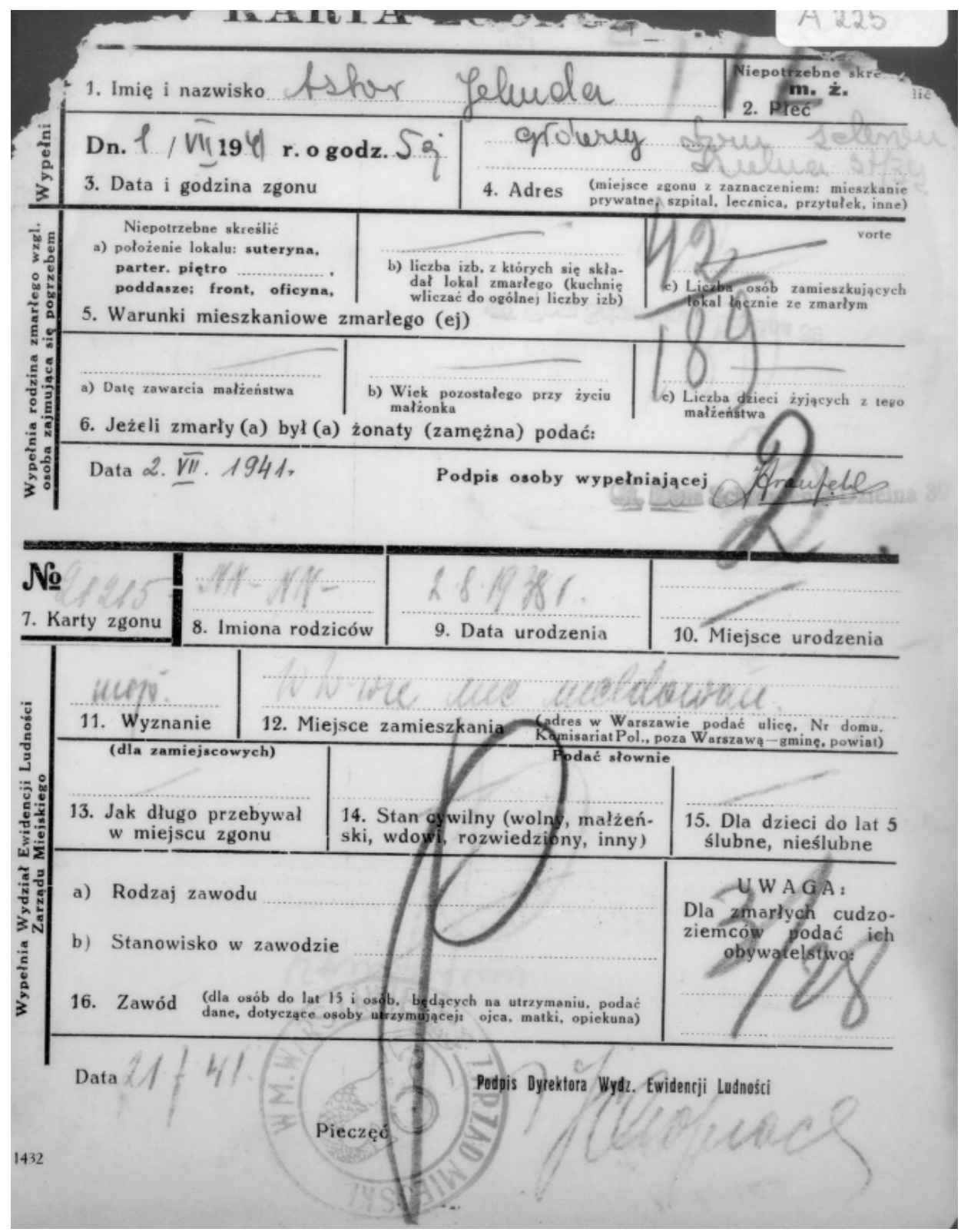

Jehuda Astor's death certificate on this and the next page (AŻIH) 


\section{Wypelnia i zakleja lekarz.}

\section{Wguisersule.}

17. Zasadnicza przyczyna zgonu, w/g której przypadek ma być zanotowany w statystyce lekarskiøj (jeżeli śøierć gwałtowna to jej charakter: zabójstwo, samobójstwo, wypadek i jakiego rodzaiu)

18. Choroby wspólistniejące

4h:

19. Powiklania

20. Rozpoznanie sekcyjne

$$
\text { Data 4. - II } 194 \mid
$$

Pieczątka

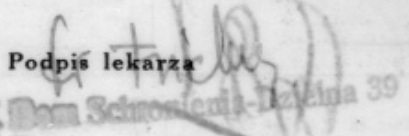

\section{Pieczątka}


What do death certificates tell us about the physicians? Primarily, they contain basic biographical information: name, surname, and address. It seems that a physician who fills in an official document is completely hidden behind it as a person, and is merely a "social role". But even in such a brief form we can find traces of personality of individual people. Clearly, they can be divided into two groups: those who maintain the medical discourse, and those who keenly go beyond it. Take for example a Dr B. Turkus of 29 Sienna St. (later of 17 Nalewki St.) ${ }^{9}$, who gives the following cause of death: "Warsaw air-raid victim" (26 September 1939) or a "war case" (9 September 1939). Thus he gives not a medical cause of death sensu stricto, but its circumstances. These words reveal protest against the reality of the war and an accusation of the perpetrators. Among the death certificates from 1941, notable are those filled in by Dr Lejpuner, a doctor at the refugee center on 35 Nalewki St., who would often give a few synonyms of death of hunger, e.g. "extreme organism emaciation", "hunger", "hunger oedema", as if he felt that a mere "inanitio", i.e. "emaciation" does not reflect the tragedy of those slowly dying of starvation, and he sought a way to voice his protest in the only manner available to him - in medical language (after all, hunger is the most common cause of death as per 1941 certificates).

Notable is another detail, one that reflects the personal situation of the physician, namely the Star of David is drawn by hand next to some of the doctor's stamps. Let us recall that from 1939, all Jewish stores and shops, including doctor's offices, had to be marked with the Star of David, and people had to wear the stigmatizing armband. As the death certificates show, some Jewish physicians had new stamps made, which bore the Star of David next to their names. Some, however, retained their former stamps, without the star. And it was they who drew this sign of their Jewishness by hand next to their name. There is something moving in their use of pre-war stamps and the gesture of the handdrawing of this sign each time. At the same time, it is a sign of protest against the stigmatizing directive and the ultimate submission to the humiliating necessity.

What do the death certificates tell us about the patients? Each is a testimony of dramatic struggle to stay alive and of ultimate defeat. The documents provide us only with the limits of individual life stories, whose complete "plot" we can only surmise. For example:

Two Arbajtman brothers, 11-year-old Moszek and 15-year-old Icek, who died of pneumonia in May 1941, within four days of each other, in a flat at 12 Lubeckiego St., where they were living with their mother.

${ }^{9}$ Addresses on the stamp reveal the predicament of Dr Turkus, whose moving out of Sienna St. was compulsory and was a result of the exclusion of the southern part of the district from the ghetto (October 1941). Similarly telling is Dr S. Apel's stamp bearing the original town name: "Grodzisk Maz[owiecki]", crossed on each document, with a hand-written annotation: "Nowolipie 7/12". 
Jehuda Astor, 3 years old, a foundling, died in the orphanage on Dzielna St., "unregistered, parents unknown, cause of death - emaciation".

Abram Dygoła, aged about 16, died in the Czyste hospital on 21 April 1941 , homeless, feet gangrenous, extreme emaciation. Death certificates document the existence of many ghetto dwellers.

Finally, an attempt at a cross-sectional look at the certificates - through the suicides noted. Among the 1939 certificates four confirm death by suicide (with one from August 1939), and in some cases the doctor's diagnosis allows us only to surmise such a cause. Among those from 1941, definitively established suicide appears seven times, and over a dozen cases give reason to surmise it.

Three surviving certificates from November 1939 clearly confirm suicide and reveal an astonishing coincidence: the suicides were women, elderly widows (61 and 76 years old, with no information about the third). In the remaining cases, the cause of death is repeated as "poisoning". It is hard to ascertain what kind of poisoning the doctor established: food or, for example, gas poisoning. On the basis of these entries we cannot decide whether those poisonings were suicides or not. But when we read the death certificates of women who killed themselves in November 1939 it is hard not to think of their feeling of being lost and threatened in the early weeks of the war, their fear of the future, and the lack of family support.

Out of 17 cases from 1941, 7 are definite suicides. Death by suicide was chosen by men and women alike (3:4). ${ }^{10}$

Among the remaining deaths, it seems that definite suicide is reflected in the formula "food self-poisoning". Others are cases of "poisoning" or "gas poisoning". Too scant information does not allow a definite qualification of the former, whereas "gas poisoning" seems to point to suicide. Who in the Warsaw ghetto, amidst skyrocketing prices, could have afforded to leave a gas faucet open;

${ }^{10}$ It is difficult to ascertain the number of suicides in the ghetto on the basis of the scant collection of several certificates. Emanuel Ringelblum noted the decline in the number of suicides among Jews against the pre-war data (cf. idem, Notes from the Warsaw ghetto. The Journal of Emmanuel Ringelblum, ed. and trans. Jacob Sloan [New York: Schocken Books, 1974], entry of December 20 1940. Let us refer to known findings: throughout 1941, when the situation was relatively stabilized, 66 suicides were noted, i.e. precisely as many as among Warsaw Jews in 1934, despite the significant increase of the Jewish population of Warsaw. Nothing indicates that the rate of suicides in 1941 was changing drastically; it seems that it had to level off at several per month. Statistics compiled by Hersz Wasser and kept in the Ringelblum Archive show seven such cases in April (cf. AŻIH, ARG I 1153), and six in June. The author of the study "Śmiertelność w getcie warszawskim" (AŻIH, ARG I 608) claims that those six cases of June 1941 were "caused by poverty". Probably out of the six suicides two were women whose death certificates survived in the collection in question. These were: Mariem Sitorek, born in 1895, a trader, committed suicide on 4 June 1941, and Rajzla Szac, who poisoned herself with gas on 6 June. Therefore the collection of death certificates, despite its accidental form, does confirm the trends noted in studies and statistics. 


\section{Dla Wydziału Statystycznego Zarządu Miejskiego w m. Warszawie}

\section{KARI'A ZGONU-II A 202}

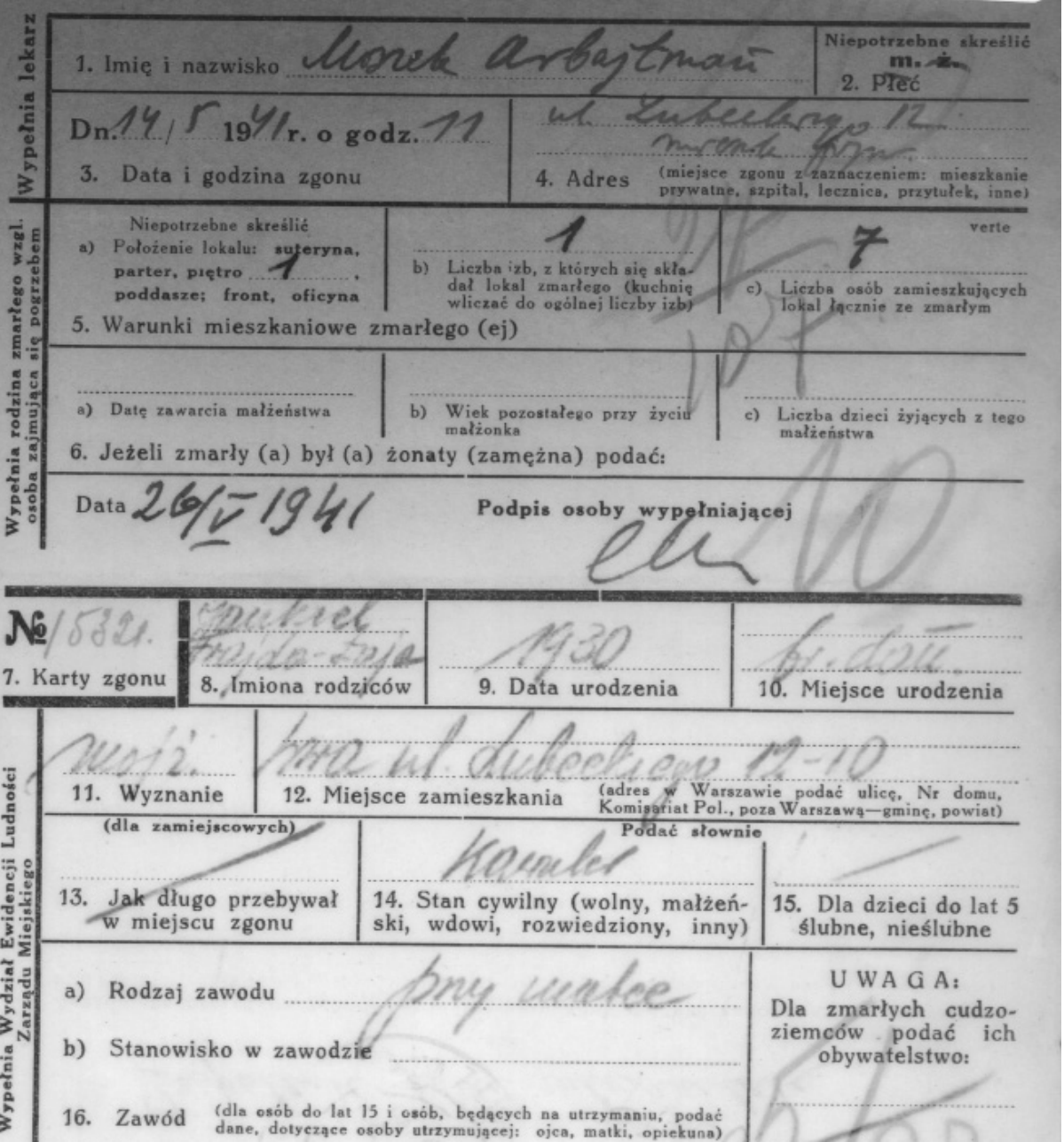

Moszek Arbajtman's death certificate on this and the next page (AŻIH) 
Wypelnia i zakleja lekarz

Zapalenir frue velasarelone

17. Zasadnicza przyczyna zgonu, wg której przypadek ma być zanotowany w statystyce lekarskiej (jeżeli śmierć gwałtowa to jej charakter: zabójstwo, samobójstwo, wypadek i jakiego rodzaju)

18. Choroby wspólistniejące

19. Powikłania

20. Rozpoznanie sekcyine

Data $4.5 .1941^{\prime}$

Podpis lekarza

d.7. ham

Pieczątka

Dr. $1 Z R$ A th MAUER 
who could have stayed alone in a flat for several hours in such an overcrowded a ghetto - these people should be deemed to have acted on purpose.

If we assume that "gas poisoning" cases were suicides, apart from the 24-year-old Szmul Finkelsztejn, they were middle-aged people and older - between 45 and 65, and one case is that of an 84-year-old woman.

Was the doctor's decision to give the cause of death his own? It appears so. The term "suicide" does appear many times next to the physician's initials. Let us reiterate that the Warsaw ghetto, in contrast to, e.g. the Łódź ghetto, was subject to a lesser degree of internal control. This is poignantly demonstrated by the example from an area that I describe below. Namely, in the Łódź ghetto the physician could not say that the cause of death was "starvation", because "no one in the ghetto could be allowed to die of hunger." ${ }^{11}$ In the death certificates from the Warsaw ghetto, the formula "dies of starvation" or "emaciation" appears repeatedly, which would show that the physician's decision to give the cause of death was independent. It is commonly held that what was happening to the Jews behind Warsaw ghetto walls was no direct concern of the Germans. Moreover, the certificates served an internal, statistical purpose (although the Germans had access to them).

It seems that the only limitation could have been the deceased's family request not to put "suicide" in official documents, as the stigma burdened the family of a suicide.

We can also suppose that doctors did not write "suicide" as the cause of death for purely definitional reasons. Ultimately, from the medical point of view, death is directly caused by poisoning or fracture of the spine; the circumstances need not be mentioned.

Another collection of official medical documents is a ledger of patients treated in the Czyste and Bersohn and Bauman hospitals, ${ }^{12}$ kept in the State Archive of Warsaw. ${ }^{13}$

${ }^{11}$ Oskar Singer, “Przemierzając szybkim krokiem getto...”. Reportaże i eseje z getta łódzkiego, trans. Krystyna Radziszewska (Łódź: Oficyna Bibliofilów and Archiwum Państwowe, 2002), 47.

${ }^{12}$ On the history of both hospitals during the war see Henryk Kroszczor, "Szpital dla dzieci im. Bersohnów i Baumanów (1939-1942)," Biuletyn Żydowskiego Instytutu Historycznego [later: BŻIH] 4 (76) (1970); Sabina Gurfinkiel-Glocerowa, "Szpital żydowski w Warszawie (na Czystem) w czasie okupacji (1939-1943)," BŻIH 1 (41) (1962), Charles G. Roland, Courage under Siege. Starvation, Disease, and Death in the Warsaw Ghetto (New York: Oxford University Press, 1992), 76 ff.

${ }^{13}$ The collection was quite accidentally attached to the "Der Obmann des Judenrates" fonds (APW, 483). How it got to the archive remains unknown. Most ledgers are from the Czyste and the Bersohn and Bauman hospitals, but there are also individual ledgers from the epidemic hospital on Chocimska St., the St. Jan Boży hospital in Bonifraterska St., Karol and Maria hospital on 136 Leszno St., St. Stanislas on Wolska St., the children's hospital on Kopernika St. and probably from the hospital on Litewska St. 
The ledgers contain lists of patients of typhus wards, both cases of typhus fever (typhus exanthematicus) and abdominal typhus (typhus abdominalis) ${ }^{14}$ at the turn of 1939 and 1940 (the earliest entries are from October 1939, the last from the summer of 1940). Inasmuch as the death certificates of Warsaw Jews were printed forms used even before the war (individual sheets, as mentioned above, from August 1939), the hospital ledgers were in German, filled in using the German language and Latin by hospital administration and forwarded to the chief municipal physician. ${ }^{15}$ Even the very form of the document is indicative of the occupation context. The documents contain basic information necessary to monitor the epidemic situation in the city. The entries in the surviving ledgers comprise a list of around 3,800 names ${ }^{16}$, the victims of the first wave of typhus. ${ }^{17}$ Each name is accompanied by a set of data, entered into the hospital ledger on the basis of patient information: age, address, "racial affiliation" (Rassengehörigheit "Jude" or "Arisch", seldom "Jude katolisch"), date of admission, record of temperature taken on three selected days, results of the Widal and the Weil-Felix test, ${ }^{18}$ accompanying symptoms (rash, dizziness), the course of the disease (light or hard), diagnosis, date of release (three possibilities: released home, quarantine $\mathrm{e}^{19}$, transferred to another ward; there is no box for death to be recorded ${ }^{20}$ ).

${ }^{14}$ One ledger contains a list of patients of the surgical ward, another of the obstetrics war of the Czyste hospital.

${ }^{15}$ One cover letter survived: from the head of the hospital on Litewska St., Prof. M. Michałowicz to Dr Schrempf, chief municipal physician (from October 1939 to February 1941).

${ }^{16}$ As the ledgers are not edited and were not included in the introduction to the inventory of "Der Obmann des Judenrates" fonds, precise calculations are difficult.

${ }^{17}$ The peak of the first wave of the typhus epidemic fell on March-May 1940. For more on the epidemic among Warsaw Jews and the role of typhus in Nazi ideology and propaganda see Barbara Engelking, Jacek Leociak, Getto warszawskie. Przewodnik po nieistniejącym mieście, second edition (Warsaw: Stowarzyszenie Centrum Badań nad Zagładą Żydów, 2013), 305 ff.; Ryszard Zabłotniak, "Epidemia duru brzusznego wśród ludności żydowskiej w Warszawie w latach II wojny światowej," BŻIH 4 (80) (1971).

${ }^{18}$ The former confirms typhoid fever, the latter - spotted fever.

${ }^{19}$ Due to the typhus epidemic, the Czyste hospital was placed under quarantine and isolated for 6 weeks (from 19 December 1939) Similar restrictions were applied in the Bersohn and Bauman hospital (until as late as February 1940). Furthermore, the Judenrat opened additional quarantine hospitals for recovering patients: On 86 Żelazna St. and 109/111 Leszno St., and in April 1940 on 53 Złota St. After the epidemic blockade was relaxed, recovering patients were also sent to their homes, which were also subject to quarantine (every house where a case typhus was ascertained was sealed for three weeks, and the residents were not allowed to leave it). From January 1941, only the quarantine on 109/111 Leszno St. was still open, where residents of an infected flat were placed for two weeks, as well as others who were to be settled in the ghetto (resettlers, returnees from camps).

${ }^{20}$ In the heading of the box, apart from the predefined Q (Quarantäne - quarantine), H (Haus - house) and S (Spezialabteilung - special ward) the doctors add: G (gestorben - died) or T (Tod-death). 


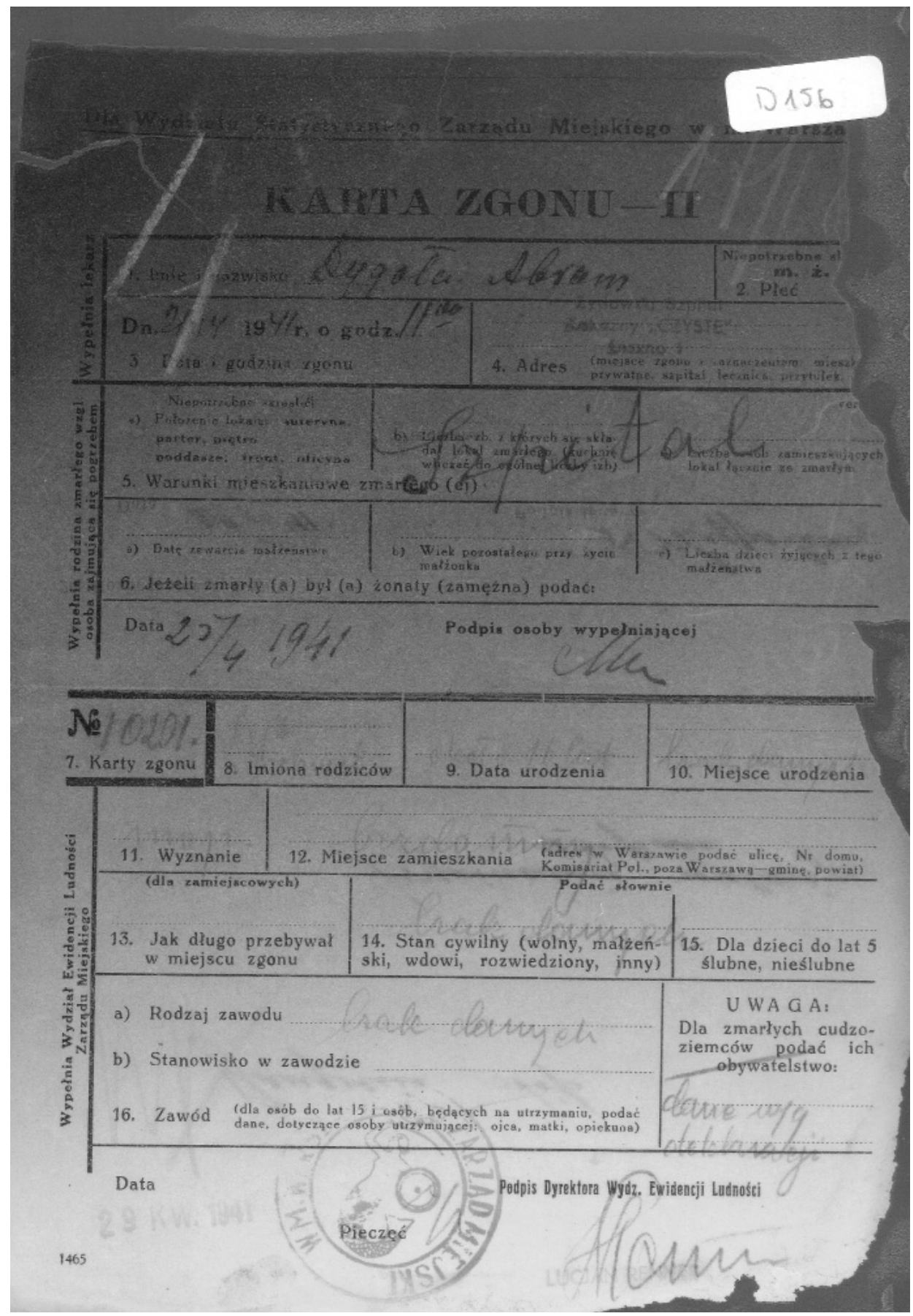

Moszek Arbajtman's death certificate on this and the next page (AŻIH) 
Wypełnia i zakleja lekarz
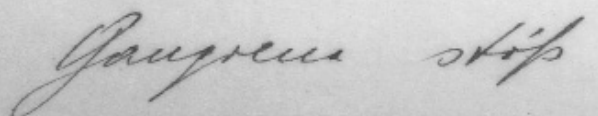

17. Zasadnicza przyczyna zgonu, wg której przypadek ma być zanotowany w statystyce lekarskiej (jeżeli śmierć gwaltowna to jej charakter: zabójstwo, samobójstwo, wypadek $\mathrm{i}$ jakiego rodzaju)

18. Choroby wspótistniejące

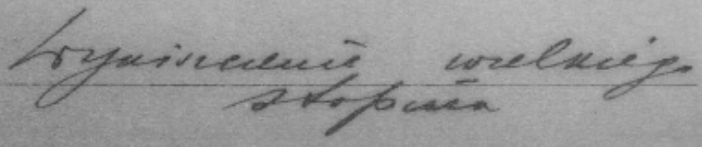

19. Powiktania

20. Rezpozmanie atketyine
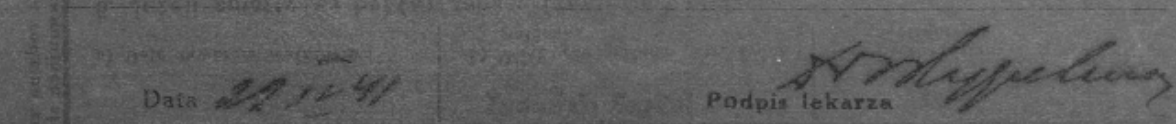

$x^{2}=$ 
Entries in hospital ledgers enable us to follow the chronology and geography of both types of typhus, as well as its social background, but they illustrate wellknown processes (although, naturally, due to the fragmentary character of the collection, the picture remains incomplete).

Hospital ledgers describe both the fate of individual families and of the entire society. A handful of examples. The poignant narration is made up of several entries that document the course of the disease of the Ejblum family of 38 Dzielna St. flat $2 .{ }^{21}$ On 4 February 1940, Chaja (aged 50, probably the mother), and children: Fryszka (aged 29), Jankiel (aged 20), Litman (aged 20), Fajwel (aged 18) and Hersz (aged 16) were brought to the Czyste hospital. All were diagnosed with typhus fever, with the rest of the family plagued with other diseases: Chaja had meningitis, encephalitis and advanced anemia. Hersz and Jankiel, who had a relatively mild typhus, left the hospital only three weeks later, but those with the most serious cases - Chaja and Fajwel - remained in hospital until late April, and were then moved to quarantine.

One day after another between 28 and 30 January 1940 members of the Palant family of 6 Twarda St. (a refugee home) were admitted: Gołda and Szoel and their children: Pesa (aged 13), Ruchla (aged 11), Josek (aged 8) and Fajga (aged 6). We do not know much about the family, and can only surmise what their fate was - flight from home (where?) ${ }^{22}$, their roaming around Warsaw, which ultimately led to the refugee shelter on Twarda St. The contemporary reader knows that the subsequent entries in the hospital typhus ledger were only a prelude to further suffering (according to the ledger all the family were cured), and the worst was only ahead of them. From this point of view, particularly impressive are records of temperature taken. They document a fleeting and precarious condition of an organism, which turned out to be the only proof that a person was alive. Out of all the elements of a person's biography, only a few most basic pieces of personal information and some variable medical parameters survived. The record of a body's fight would survive several decades after the patients' death - some of them later died in the ghetto of hunger or disease, and the rest were murdered in the so-called liquidation operations. Their obituaries are thermometer readings, a record of the body fighting a disease.

Entries in hospital ledgers also illustrate the topography of typhus, with subsequent entries made for residents of the same tenement. At the turn of February and March 1940, residents of 18 Wolska St. go down, the Hamersz-

${ }^{21}$ In some ledgers, even if the individual family members are not noted, we can find annotations on the patient's family situation, e.g. "brothers and sisters - typhus symptoms, the mother died of typhus 4 weeks ago" (cf. APW, 483/55, 56). Such annotations can be somewhat helpful for genealogical research.

${ }^{22}$ Perhaps it was the first wave of people who arrived in Warsaw between November 1939 and October 1940. These were Jews from territories incorporated into the Reich. Some Jewish inhabitants of these territories, compulsorily resettled, fled precisely to Warsaw. 
tejn, Michlewicz, Moralny, and Opatowski families. In late March the typhus epidemic breaks out in Nalewki, Sapieżyńska, Muranowska, Ostrowska, and Krochmalna streets. At the turn of April and May, the Bersohn and Bauman hospital admits the children of the Handelsman, Urensztajn, Rykman, Gutfinger families of 9 Krochmalna St. [...] As time goes by, the type of patient changes as well "pure typhus cases" give way to the chronically ill and emaciated; more and more often the physician adds accompanying diseases: scabies, anemia, phlegmon, pneumonia, tuberculosis, pressure ulcers, dementia. Hospital records illustrate the chronology of gradual pauperization and weakening of physical and mental strength of the Jewish community under occupation.

These considerations are an attempt at reading non-narrative official medical documents. It seems that the more they were intended as a dry text, a medical document for statistical purposes, which was to hide the individual character of the patients, the more they should be decoded and read empathetically. Non-narrative documents such as death certificates and hospital ledgers contain a potential "lurking" narration, one that contains mere traces of existence of murdered Jews.

Translated by Jerzy Giebułtowski

\begin{abstract}
This paper presents two archival collections: death certificates of the Warsaw Jews (1939 and 1941), from the archives of the Jewish Historical Institute, and a collection of books kept in the State Archives in Warsaw, containing names of patients treated in 1939 and 1940 in the hospital at Czyste, and in the Bersohn and Bauman hospital. These collections are a part of official medical records, which today can be read as a record of the fate of the Warsaw Jews. These non-narrative documents are not the just the only testament to the existence of people claimed by the Holocaust, but they also reveal various aspects of their history to the modern reader, they become elements of a great historical fresco.
\end{abstract}

\title{
Key words
}

Warsaw ghetto, typhus, suicide, death certificates, hospitals, medicine 